As regards the compounds of my firm, I may state that it is quite true that at one time the coefficient 4 was guaranteed and published for Jeyes' Fluids, but for some time past it has been guaranteed at 5 , and I should like to add that it is retained at only 5 in order to admit of adding certain other properties which fit Jeyes' Fluid for use as not only a reliable bactericide, but also an insecticide, a deodorant, and a nontoxic general cleanser, making it, we claim, the best and safest all-round disinfectant for household use. The coefficients of our various products are guaranteed to range from 5 to 22 , according to the purpose for which they are required. For example, where a strong bactericide only is wanted-as in public health work, \&c.--we offer our Special Fluid Cyllin; and where the only water available for purposes of dilution is very hard, salt, or brackish we recommend crude Cyllin. In this connexion the following independent results obtained from samples of Jeyes' Fluids bought in the open market have recently been published :-

$\begin{array}{lrrrrrl} & & \text { No. 1. } & & \text { No. 2. } & & \text { Date of test. } \\ \text { Professor Klein } & \ldots & 5 \cdot 0 & \ldots & 4 \cdot 4 & \ldots & \text { July 29th. } \\ \text { Professor Hewlett } & \ldots & 4 \cdot 0 & \ldots & 4 \cdot 2 & \ldots & \text { August 12th. } \\ \text { Dr. Rideal } & \ldots & 5 \cdot 4 & \ldots & 5 \cdot 0 & \ldots & \text { July 26th. }\end{array}$

Professor Hewlett's figures as well as that for No. 2 obtained by Professor Klein, are slightly lower than the present standard for both fluids-viz., 5.0-and are doubtless due to the fact that in these cases they were working with specimens drawn from older stocks, at the time of manufacture of which the guaranteed coefficient was only $4 \cdot 0$.

My company is prepared to stand by any guarantee issued over its signature, and I, as their scientific adviser, am prepared to demonstrate the validity of those guarantees to any. one sufficiently interested, including the members of your Commission.

THE LANCET claims to have an unbiassed mind and to be desirous of avoiding acrimony, and yet even the casual reader must see that in the Commissioners' report, as also in their replies to criticisms on that report, the products of my company are specially singled out for direct attack.

If there is any one firm in the industry in question to whom credit is due for an honest attempt to produce a method of scientifically standardising disinfectants for the benefit of those interested in the health of the community, and by which the individual consumer may obtain a known disinfecting value, that firm is the one with whom I have the honour to be connected.

I am, Sir, yours faithfully,

For Jeyes' Sanitary Compounds, Co., Limited,

J. T. AINSLIE WALkER, Managing Director.

64, Cannon-street, E.C., Dec. 24th, 1909.

* $*$ Our Commission had not the origin which Mr. Ainslie Walker states. He need not wonder at all at its reason : it followed on the fact that the previous Commission to which he alludes had not settle 1 matters. The report of that Commission was not adopted according to its chairman, Mr. Wynter Blyth, who wrote to that effect to us (see THE LANCET, Dec. 26th, 1908, p. 1942). With regard to whether our Commission is correct or Dr. Rideal we are satisfied with our findings. The accusation of personal bias is unwarranted.-ED. $\mathrm{L}$.

\section{CIVILISATION AND THE CORSET.}

To the Editor of THE LANCET.

SIR,-Mr. Heather Bigg's arguments in favour of the modern corset are rather far-fetched. There can be no possible support to the extra (the generative) female organs. The fact that pressure-it need be by no means excessive-is exerted upon the abdomen, and particularly, as is the case with corsets, at the waist line, must cause a corresponding amount of pressure upwards towards the diaphragm, \&c., and specially downwards upon the organs in the pelvic cavity.

Two reasons why corsets cause the abdominal organs to gravitate towards the lower abdomen and pelvic cavity are (1) constriction at the waist; (2) by withdrawing the necessity for the abdominal muscles to exert their normal supportive force, and thereby weakening them from lack of use, they consequently "give" in the part least protected artificially and of least resistance-viz, the lower abdominal region.
It is not correct to say that Nature ordained that woman should breathe pectorally. She does so not because Nature ordains it but because her corset makes it impossible for her to do otherwise. If Nature ordained that she should breathe pectorally then Nature is not consistent, since the civilised woman must have been made from a pattern quite different to that upon which her uncivilised sister was made. The latter breathes both pectorally and abdominally-i.e., naturally_as do both civilised and uncivilised men. It is also remarkable how little need there appears to be among native women for abdominal support. They scorn corsets, and very seldom is there a case of uterine prolapse or undue protrusion of the lower abdominal wall even after having borne many children.

With regard to men wearing corsets, I think Mr. Heather Bigg must mean abdominal belts, very different articles indeed. I have travelled in a good many parts of the world, both tropical and temperate, and have never seen a man wearing a corset, as a corset and not an abdominal belt, for support. Of course, we have all seen men who wear corsets, but they are worn for the sake of the figure only. I suppose every medical man has at some time ordered an abdominal belt for some patient or other, but I do not think many, if any, of us have ordered men to wear corsets. I do not, however, wish to underrate the importance of the corset to the modern woman. From long use it has become a necessity, and after once getting accustomed to it she cannot well do without it, especially when we take her mode of dress into consideration. It is, however, a strange thing (and quite contrary to Mr. Heather Bigg's argument) that the stouter the woman the less does she desire to wear corsets. A thin woman will never go without them; a stout woman prefers to discard them, and especially is this the case in hot weather, notwithstanding Mr. Heather Bigg's assertion to the contrary.

There is one point which I should like to mention with regard to the corset of the present day. I have lately had quite a number of cases of pain and tenderness in the breast, accompanied, or preceded by, more or less inflammation of the nipple, which the usual remedies failed to cure. I found in every case that the cause of the trouble was an irritation of the nipple by the upper edge of the corset, which just reached to or a little below the nipple, which was thus constantly exposed to friction or squeezing. To make matters $n$ orse there was in every case either a whalebone or steel support just in the nipple line. I ordered that the corsets should be altered so as to give ample room to receive and support the breast and to reach well above the nipple. The trouble rapidly disappeared without further treatment. Unless this detail in the manufacture of the corset is corrected I fear it will give rise to considerable trouble to many women in the near future. - I am, Sir, yours faithfully,

Leigham Court-road, S.W., Dec. 9th, 1909. JAMES KIRKLAND.

\section{AN OVERSIGHT.}

\section{To the Editor of THE LANCET.}

SIR, - In the Section of Dental Surgery comprised in your admirable Annus Medicus published in your last issue there is an error which occurs three times, which I am sure you would wish to have rectified. Three papers, by Dr. Theodore Shennan, Mr. A. O. Lockett, and Mr. D. M. Shaw respectively, are mentioned as having appeared in Dental Proceedings of July, June, and May, 1909. There is no such publication-to my knowledge-as Dental Proceedings. These papers appeared in the July, June, and May issues of the Dental Record. Trusting you will be good enough to make this correction,

I am, Sir, yours faithfully,

Dec. 26th, 1909. WM. RushroN, Editor, Dental Reoord.

*** We regret the slip.-ED. L.

\section{A WARNING.}

To the Editor of THE LANCET.

SIR, - A young man claiming to be my relative has recently called on several meducal practitioners in the London suburbs. He inquires for lodgings in the neighbourhood and then borrows money from the landlady to whom he has 